Secondary publication on the edoc server of the Humboldt-Universität zu Berlin

$$
\text { https://doi.org/10.18452/21592 }
$$

This is an Accepted Manuscript of an article published by Taylor \& Francis in Journal of Environmental Policy \& Planning on 27/05/2019, available online: http://www.tandfonline.com/10.1080/1523908X.2019.1623658

Originally published as:

Ourania Papasozomenou, Timothy Moss \& Natàlia García Soler (2019) Raindrops keep falling on my roof: imaginaries, infrastructures and institutions shaping rainwater harvesting in Berlin, Journal of Environmental Policy \& Planning, 21:4, 358-372, DOI:

$\underline{10.1080 / 1523908 X .2019 .1623658}$

\title{
Raindrops keep falling on my roof: imaginaries, infrastructures and institutions shaping rainwater harvesting in Berlin
}

\author{
Ourania Papasozomenou, Timothy Moss, Nathàlia García Soler
}

\begin{abstract}
Studies of rainwater harvesting regularly highlight the rich diversity of technologies used for rainwater harvesting in cities, but rarely devote attention to the equally diverse logics driving rainwater harvesting projects (RWHPs). To rectify this omission this paper presents research from a city - Berlin - which has a long pedigree of rainwater harvesting that has given rise, over the past 30 years, to an astonishingly varied range of schemes. We analyse and compare three cases encapsulating three distinct project types prevalent in the city: public, grassroots and commercial. The paper demonstrates the nature of diversity between the three and illustrates how diverse logics of rainwater harvesting co-exist within one city. More fundamentally, it unpacks these logics using concepts of sociotechnical imaginaries, urban infrastructures in transition and institutional obduracy and change. It is demonstrated, thereby, how each project reflects a particular imaginary of why urban rainwater should be harvested, how and for whom, and how these imaginaries have emerged out of particular institutional and infrastructural contexts in
\end{abstract}


the course of Berlin's post-reunification development. The paper concludes with reflections on the implications of this conceptually grounded, cross-case comparison for environmental research and policy.

Keywords: Rainwater harvesting, institutions, imaginaries, urban infrastructure, Berlin

\section{Introduction}

Rain falling on roofs and other non-permeable surfaces has always posed a challenge for densely-populated, built-up areas. The conventional management response in industrialised countries has been to dispose of this rain via underground pipes to the nearest watercourse. The pollutive impact of this practice and the increasing volatility of stormwater events as a consequence of climate change are revealing the severe limitations of these large-scale, hardengineering solutions. Alternatives are being promoted which aim to retain rainwater closer to where it falls, either allowing it to percolate locally or using it as a substitute for drinking water. These go under a variety of names, ranging from Sustainable Urban Drainage Systems (UK), Water Sensitive Urban Design (Australia) and Low Impact Development (USA) to the Sponge City (China) (Brown et al. 2013; Madsen et al. 2017). Despite its growing popularity in professional circles, urban rainwater harvesting (URWH) has largely failed to move beyond environmental policy aspirations. For all the talk of mainstreaming these proven technologies there are precious few cities in the developed world - such as Melbourne - that can justifiably claim to have made this transition (Brown and Farrelly 2009; Brown et al. 2013).

Explanations for the limited dissemination of URWH point not to any technical deficiencies of these alternative rainwater management systems but to the obduracy of existing institutions and infrastructures and scalar inconsistencies of environmental policy (Jensen et al. 2016). Social science studies have identified a number of institutional barriers, ranging from unfavourable regulatory frameworks to a lack of political will (Brown and Farrelly 2009; Cettner et al. 2014). 
They also draw attention to the strong path dependencies at work in water infrastructure systems that confound sociotechnical transitions (De Haan et al. 2015; Fuenfschilling and Truffer 2014). As a way forward, scholarly interest has focussed on the analysis of sites of experimentation in particular cities (Bos and Brown 2012; Nickel et al. 2014) and enabling contexts for the uptake of URWH technologies and practices (Bos and Brown 2012; Cettner et al. 2014).

What is largely missing in these studies is an appreciation of the diversity of rainwater harvesting that can exist within any one city. Case studies of cities tend to select one pilot project only for detailed analysis, often leaving the reader in the dark as to whether the single case is a one-off intervention or representative of a particular type of project. In this paper we argue, by contrast, that a city can harbour multiple types of rainwater harvesting projects and that these projects can differ substantially, in terms of actor aspirations, technological design, policy incentives, institutional settings and so on. Appreciating these differences requires a finer understanding of the interaction between rainwater harvesting projects and their sociotechnical and spatial contexts. Such knowledge can point towards bespoke ways of promoting diverse URWH projects within a single city.

To this end, this paper presents research from a city - Berlin - which has a long pedigree of rainwater harvesting that has given rise, over the past 30 years, to an astonishingly varied range of schemes. From a database of over 250 rainwater harvesting projects ${ }^{1}$ we select, analyse and compare three projects which encapsulate distinct types prevalent in the city: public, grassroots and commercial. The purpose of the paper is threefold: firstly, to explore the nature of the diversity between the three projects in terms of the actors involved, policies framing the project, technologies installed and their implementation; secondly, to illustrate how each project reflects a particular imaginary of why urban rainwater should be harvested, how and for whom; thirdly,

\footnotetext{
${ }^{1}$ For a comprehensive account and analysis of the database, please refer to XXX 2018, a parallel study conducted by the authors.
} 
to explain how these project logics have emerged out of particular institutional and infrastructural contexts in the course of Berlin's post-reunification development.

The paper begins by placing the study in the context of current debates at the interface between science and technology studies (STS) and human geography. These relate to: sociotechnical imaginaries, urban infrastructural contexts and institutional settings for rainwater harvesting. The following empirical section describes each of the three URWH projects in Berlin according to a common analytical template. Subsequently, the three projects are interpreted and compared in terms of the concepts discussed in the literature review. The paper concludes with reflections on the implications of this conceptually grounded, cross-case comparison for environmental research and policy.

\section{Imaginaries, Infrastructures, Institutions: sociotechnical readings of urban rainwater harvesting}

It is only recently that the rich literature on sociotechnical transitions has been applied by social scientists to study urban water transitions. The handful of publications now available all ascribe to a sociotechnical understanding of urban water systems, i.e. one that sees material and technological objects thoroughly enmeshed in society. Some focus on experimentation and the social learning it can generate to overcome system lock-in (Bos and Brown 2012). Others draw on various typologies of transition pathways to map stages of development from, for instance, take-off to stabilization (Ward et al. 2012; Brown et al. 2013; De Haan et al. 2015; Madsen et al. 2017). Although most of these contributions use urban case studies to illustrate and explicate their analysis, only one recent publication was identified that addresses the spatial dimensions of urban water transitions explicitly (Fuenfschilling and Truffer 2014). Even these authors, however, fail to demonstrate how spatiality might influence - or be influenced by - the institutional logics central to their analysis. 
The importance which they and others ascribe to the institutional dimensions of sociotechnical transitions towards URWH provides, though, some important pointers for our own work. Fuenfschilling and Truffer (2014) highlight the coexistence of competing logics of urban water, explaining implementation problems for URWH in Australia in terms of misfit with the dominant 'Hydraulic Logic'. Cettner et al. (2014) attribute the slow pace of change from piped to surface-based systems of urban drainage to institutional inertia. Bos and Brown (2012) demonstrate the importance of institutional contexts for influencing change to cultures, structures and practices of urban water management.

Helpful though these contributions are, they are inadequate to meet fully the three objectives of this paper. We are interested here in i) illustrating visions and imaginaries that guide actors in engaging with URWH projects, ii) unpacking urban-infrastructural relations and iii) understanding the institutional setting framing URWH. For this purpose, we draw on three recent strands of research that address our core areas of interest, each from a different perspective: sociotechnical imaginaries (i), urban infrastructures in transition (ii) and institutional obduracy and change (iii). Whereas the perspective of urban-infrastructure relations was drawn from the research project within which this research was conducted, the other two perspectives were included specifically to meet the design of this paper. Engaging with them allows for a broader grasp of the drivers and obstacles behind URWH in Berlin. Each analytical perspective is now assessed for its merits and relevance to the paper's objectives.

\section{Sociotechnical imaginaries}

The concept of sociotechnical imaginaries was coined by Jasanoff and Kim (2009) to show how visions of future possibilities are embedded in the social organisation and practices of technology. Conceptually, it combines work on the construction of imaginaries in political theory and on sociotechnical systems in STS. Jasanoff (2015) has recently opened up the meaning of sociotechnical imaginaries to apply to any organised groups (not just nation states), 
to encompass the visions of individuals as instigators of collective imaginaries and to consider the coexistence of multiple (competing) imaginaries within a society.

The relevance of the concept of sociotechnical imaginaries for this paper lies in the attention it pays to (diverse) visions underpinning URWH technologies in particular contexts. According to Jasanoff (2015), its explanatory powers are fourfold. Firstly, it can help explain difference in societal responses. Secondly, it addresses time by revealing how futures get bound up in legacies from the past. Thirdly, it is attentive to space and the importance of spatial imaginations. Fourthly, it explicates the relationship between collective formations and individual identity. Intriguingly, the first three aspects - difference, time and space - are central to our own scholarly endeavour. The concept lends itself, in particular, to comparison, which is - in Jasanoff's words - "perhaps the most indispensable method for studying sociotechnical imaginaries" (2015, p. 24). This is also our principal method of analysis.

\section{Urban infrastructures in transition}

Within the growing scholarship on transitions in sociotechnical systems attention has been recently paid to the urban scale and what the 'urban' can mean to transitions. This emergent body of scholarship at the interface between urban studies and technology studies is predicated on the notion that cities and their infrastructure systems are co-constitutive; that is, cities both shape and are shaped by infrastructures (Coutard et al. 2005; Bulkeley et al. 2011; Wolfram and Franzeskaki 2016). Being attentive to urban contexts and contingent events, this literature conceives of change as often messy, contested und inconclusive (Jensen et al. 2016). It is keen to highlight how sociotechnical transitions become embroiled in broader processes of urban change (Hodson and Marvin 2010).

From this perspective urban development is not just the backdrop, but an intrinsic part of urban water transitions. How urban politics, urban structures or urban economies sustain or hinder URWH policies and planning is, therefore, a key area of inquiry. If we regard the complexity and dynamics of a city as constitutive to urban water systems, then we need to be attentive to 
both diversity and fluctuations in transition processes around URWH. Following Coenen et al. (2012), it is important for us to consider the socio-spatial relations within which transitions evolve and the institutional embeddedness of rainwater management policies and practices.

\section{Institutional obduracy and change}

This brings us to the third strand of literature pertinent to our study: institutionalist approaches to sociotechnical systems. Institutions - understood broadly as formal and informal rule systems enabling or constraining human action - are familiar territory to transitions research. Institutionalised solutions established in the past set the scope for policy actions available in the present (Tennekes et al. 2014). The path dependence of regulatory frameworks and institutional logics is, indeed, a common explanation for sociotechnical obduracy and features prominently in transitions studies (Geels and Schot 2007).

On a meta-level, it has been asserted that modern infrastructure systems and dominant forms of governance are inextricably interconnected (Mayntz and Schneider 1995). Case studies have since demonstrated that this interdependence is not as rigid as it might appear. Whilst (in)compatibility between certain technologies and certain institutional arrangements does exist, the success of new technologies is influenced strongly by many other factors, such as socio-economic trends, competing technologies and the strategies of relevant actor groups (Rohracher 2007). This points to a more nuanced and dynamic understanding of relations between technology and institutions. Furthermore, institutions are not only a means for organising society and its options through policies. They also frame the context in which policy options are developed (Tennekes et al. 2014).

We can thus treat institutional settings of URWH in Berlin not simply as a constraint to innovative technologies and practices in urban water management but also as a contextual factor that can be adapted through human agency, reflecting matters of concern of the past (Jensen et al. 2016). By exploring case studies that, together, span a period of 30 years, we are able to 
observe and interpret changes to the institutional arrangements shaping rainwater management and the role of actors in shaping institutional change.

These three analytical lenses - sociotechnical imaginaries, urban infrastructures in transition and institutional obduracy and change - will be used to guide the cross-case comparison. First, though, we outline the three case-study projects of URWH in Berlin.

\section{Public, Grassroots, Commercial: three approaches to URWH in Berlin}

Berlin can pride itself in having spawned abundant and truly varied URWH projects throughout the city since the mid-1980s. Over 250 projects were identified and analysed in a parallel study by the authors (XXX 2018), where the focus lay on mapping diversity in terms of the timing, geographical location, technical design and size of these schemes in a large- $\mathrm{N}$ survey. This paper, by contrast, selects three case studies from our database that can be regarded as emblematic of the diversity of URWH schemes encountered in Berlin at particular times during the past 30 years and subjects them to in-depth analysis and comparison. The cases were selected based on the following criteria: firstly, their representativeness of prevailing projects at the time of their implementation; secondly, their advanced stage of development permitting analysis of process from design to use and, thirdly, accessibility to primary data (especially via interviews) in the absence of case-specific secondary material. Each selected case study represents a particular type of project that emerged from our research that we term 'public', 'grassroots' and 'commercial'. Based on a parallel study (XXX 2018) we established that each of the three categories of projects was prevalent at a particular time and reflected a particular institutional context. The public projects were prominent in the mid-1980s, when the city government could afford generous subsidies. Grassroots projects from the 1990 s to early 2000 s are expressive of Berlin's alternative housing culture at that time. Commercial projects became common after the early 2000s in response largely to economic incentives to retain rainwater on site. The research method involved analysing the little available written project documentation, 
a total of 30 in-depth and semi-structured interviews, inputs generated from a stakeholder workshop (involving representatives from the projects, city and borough councils), site visits to all three projects and a survey of the residents at the Sonnig Wonnig site. The interviews were conducted with key actors involved in each case, comprising primarily borough and city-state officials, project initiators, engineering consultants and residents between March 2015 and January 2017. All interviews were transcribed and analysed following the deductive coding method. The codes were developed before the data collection process began, based on the three analytical categories described above (e.g.: visions_space; visions_collective; urban infr_politics; institutional_constraints; institutional support; legacy), which we operationalised for analytical purposes and then merged in emerging themes (e.g.: connectivity; collective visions; legacy; challenges). .

In this section the three URWH projects are profiled in brief, prior to comparative analysis in the following sections. Table 1 summarises the principal characteristics of each project

[Table 1 here]

\subsection{Berliner Strasse}

The Berliner Strasse settlement is a major housing project $\left(32.000 \mathrm{~m}^{2}\right)$ planned and implemented by city and borough authorities between the late 1980s and early 1990s. It represents an early generation of URWH projects organised and funded by the local state to demonstrate how new social housing could be ecological in design and use. It became one of the largest housing developments in post-reunification Berlin.

\section{Context}

The estate is located in Zehlendorf, a well-off borough, located in the south-western periphery, with the lowest unemployment rate in Berlin (Meinlschmidt 2013). The area was not facing any particular water-related problems requiring rainwater retention or reuse. The availability of the 
site was the prime reason for its development. Nevertheless, the settlement was relatively close to a water protection zone and options for URWH were enhanced by the relative ease with which rainwater could be diverted from the existing separate rainwater sewer system.

\section{Objectives}

The objectives of the housing settlement were essentially three-fold: to combat a housing crisis in what was then West Berlin, to present Berlin to an international audience as a pioneer of green buildings and to demonstrate how ecological design could be incorporated into social housing, benefitting less well-off tenants as well as homeowners.

\section{Technology}

The rainwater system installed in the settlement collects, retains and uses rainwater in a drainage area of approximately $25.000 \mathrm{~m}^{2}$ (cf. GSW 1999). Water is collected in three underground cisterns, one for each of the settlement's zones, and used to water the green areas and to feed a stream, designed as a biotope, which ends in a pond.

\section{Actors}

The Berlin Senate was the initiator of the project, supporting it by linking social housing funding to the implementation of ecological measures. As Berliner Strasse comprises large public spaces (open spaces, a stream and a pond), the borough of Zehlendorf was given a key role in the construction as well as the maintenance of these systems, which are surrounded by private land on the settlement.

Three public housing associations each constructed and subsequently operated one of the three plots of the settlement. When one of these housing companies was privatised in 2002 (XXX 2018) serious maintenance problems emerged (Interview 1). Intriguingly, local residents have filled this gap by organising clean-up activities and occasionally paying for the pond's maintenance themselves (Interviews 1 and 2). 


\section{Implementation}

Since the project's completion no assessment has been made of how the rainwater harvesting technologies have influenced water consumption. Those active in developing the project originally (i.e. public authorities, public housing associations) have shown little interest in its subsequent performance. There has been no clear distribution of responsibilities and liabilities on the site, leading to suboptimal maintenance of the rainwater harvesting system, "the weakest link of the project" (Interview 8). On the plot owned by the now privatised company it is now the residents that ensure the operation of the water stream and pond is unobstructed (Interviews 1 and 2). Residents in the Berliner Strasse value the social network that has emerged through their interaction with the technology, making them feel "like being in a big family" (Interview 9), although "it is no longer as it used to be" (Interview 10).

\section{Legacy}

Components pioneered at Berliner Strasse have been adopted in other developments in the city, but public housing projects of this scale and magnitude have not been replicated since, owing largely to Berlin's budget crisis in the 1990s and a subsequent shift in priorities for URWH (XXX 2018). Interestingly, though, Berlin is today facing a renewed shortage of housing, "regenerating interest in novel ways of combining affordable rents with high ecological standards in public housing" (Interview 3).

\subsection{Sonnig Wonnig}

This grassroots project is representative of a host of others in Berlin in which storing and using rainwater is a core component of alternative modes of communal living. Initiated in 2000 by two colleagues, a planner and an architect, the Sonnig Wonnig project was set up to demonstrate that living in an ecologically sustainable way is technologically and economically feasible in an urban setting (Interview 4). 


\section{Context}

The Sonnig Wonnig community is located in the borough of Lichtenberg, a traditional industrial quarter to the east of the city centre that has, since reunification in 1990, suffered from deindustrialisation and high levels of unemployment. For this reason city authorities have targeted the borough for commercial development (Senatsverwaltung für Stadtentwicklung, 2011a) and for bio-climatic improvement within the context of the Urban Development Plan on Climate Change (StEP-Klima). Lichtenberg was also part of the city's Social Urban Renewal Programme. At the time of implementation there was no particular rainwater management problem locally, though the risk of stormwater flooding has since increased owing to urban development in Lichtenberg (Interview 5).

\section{Objectives}

The two initiators wanted to show that what they had been taught in their universities about environmentally sustainable forms of living could be applied in real life without compromising on modern comforts (Interview 4). Having bought an empty apartment building in Lichtenberg, they set out to refurbish it along ecological principles, enroll like-minded residents and engender a collective model for using the property. Berlin provided an ideal base for this venture, as "it was known [to us] that Berlin offered such opportunities, it was common knowledge" (Interview 5). For staff at the borough administration the project could test the viability of ecological experiments in a densely populated urban setting (Interview 6) and help counter Lichtenberg's negative public image. The borough was looking for exemplary projects that could act as "beacons, shining over Lichtenberg" (Interview 6).

\section{Technology}

The rainwater component of Sonnig Wonnig comprises a complex system of collecting, treating and reusing water (rainwater as well as greywater), custom-designed for the refurbished building. Rainwater is managed by two different systems, one directed to a garden pond and the second one used for washing machines, toilet flushing and watering the garden. Water reuse 
is so effective that the only water discharged to the public sewer is black water mixed with some waste kitchen water.

\section{Actors}

As a grassroots project, Sonnig Wonnig was conceived, planned and implemented by the two initiators collaborating with an engineering company that supervised the installation of the water and energy systems. The initiators formed a limited joint-stock partnership (KG) which owns the property and the building. The residents are organised in an association that manages the rent contracts between them and the KG. Profit-making is forbidden so as to avoid speculation.

This project has benefited from the strong support of staff at the borough administration, as the project fits nicely to the borough's policy of improving Lichtenberg's reputation by greening the urban environment and attracting young families. They facilitated the granting of necessary permits and enabled some funding, under the "Social Urban Renewal" programme, in exchange for certain quality standards and legally binding maximum rents.

\section{Implementation}

More than fifteen years after its completion the project is fully functional - technically, economically and socially - as both the initiators and the residents testify (Interview 5 and residents' survey of March 2016). Through rainwater reuse and water conservation, drinking water consumption has been reduced by $85 \%$ (Interview 5 ), saving considerably on rainwater, wastewater and drinking water fees. What is more, rents have been kept low and affordable, in accordance with the social aspirations of the project. Communal areas have been created, promoting cohesion and bonding between the residents.

\section{Legacy}

The borough administration, encouraged by the project, has since cooperated with the initiators on other eco-friendly projects in the area. However, this project was, as one official stated, an “exception", which has not been replicated elsewhere (Interview 6). Many small residential 
projects have included some rainwater harvesting components and some have taken a similar approach, but few are as comprehensive and multi-faceted as Sonnig Wonnig (Interviews 5 and 6). The initiators of Sonnig Wonnig report having tried replicating some of the technologies in other projects but finding that the regulations for using treated waste- and rainwater have, in the meantime, become stricter and less conducive to water recycling technologies.

\subsection{IKEA Lichtenberg}

The case of IKEA Lichtenberg is exemplary of a more recent generation of URWH projects on commercial properties. Since the early 2000s businesses have emerged as key players of URWH in Berlin. This is due primarily to the sharp rise in wastewater tariffs (Berlin's wastewater tariff is one of the highest in Germany) and the possibility to reduce wastewater bills by taking advantage of a novel split tariff that rewards on-site rainwater retention (Nickel et al. 2014). This consists of a fee per square metre of sealed area for each property that can be reduced or waived where surfaces are partially or fully permeable (Schütze 2013).

\section{Context}

This commercial project emerged out of the construction of IKEA's new branch in the borough of Lichtenberg. It is part of Berlin EastSide, the city's largest commercial zone and a privatepublic-partnership ${ }^{2}$ shared by two boroughs, Lichtenberg and Marzahn-Hellersdorf. The idea of establishing an IKEA branch in the Eastern part of the city had been considered since the mid-1990s, but did not become a reality until 2010 (Peters, 2010).

\section{Objectives}

IKEA Lichtenberg is designed as the most sustainable IKEA building in Europe. Whilst the principal thrust of the project is on energy efficiency - notably solar power and using heat from wastewater - rainwater collection and reuse is also an integral component of this show-case for

\footnotetext{
2 The private-public-partnership includes the two borough administrations and five private companies, among them the Berlin Water Company (BWB) and IKEA.
} 
IKEA's commitment to environmental and climate protection (IKEA 2014; 2010). Cost-saving is an additional motive for retaining and reusing rainwater on site.

For the two borough administrations the IKEA Lichtenberg branch helps make the area more attractive for commerce and industry (Bezirkamt Lichtenberg von Berlin, 2012). At the official opening the Senator of the Environment called it "a pilot scheme that is of great interest for major construction projects" (Tagesspiegel 2010). The borough's environmental office is keen to support on-site rainwater retention to counteract the effect of increased land sealing (Interviews 5 and 6), but it is unclear whether this policy influenced the IKEA project.

\section{Technology}

Rainwater is collected from the store's roof by inlets and directed to a $450 \mathrm{~m}^{3}$ underground concrete cistern. Once filtered, the rainwater is used for flushing all the store's toilets and for watering the plants in the store's greenhouse. At full capacity, the cistern holds enough water to flush all the store's toilets for three weeks (IKEA 2010). The rainwater tank is connected to the public sewer in case of an overflow event, but this had never been used when our interviews took place (March 2016). An additional feature of the store is a heat recovery system from the wastewater sewer that heats the building during the winter and cools it during the summer. This covers around $70 \%$ of the store's annual energy consumption (cf. Klimaschutzpartner n.d.).

\section{Actors}

This project was a commercial endeavour, initiated and financed solely by IKEA Sweden and its subsidiaries. Two engineering companies designed and supervised the construction of the branch. The two boroughs and the Berlin Senate administration facilitated the project, approving the construction plans and issuing the pertinent permits. Some local residents were significant in delaying the planning process. Concerned about traffic congestion they took legal action, demanding better public transport links to the IKEA branch (Interview 7). 


\section{Implementation}

IKEA Lichtenberg seems to have achieved what it set out to. It is one of Europe's most environmentally friendly commercial buildings, powered largely by renewable energy produced on site and saving considerable amounts of energy with an innovative heat recovery system using the municipal wastewater network. Through the installed rainwater harvesting and reuse system, IKEA managed to reduce its estimated drinking water use by $50 \%$ (information on site visit, March 2016). The URWH measures at IKEA Lichtenberg have helped the company save costs of water consumption and rainwater disposal and promote its green image.

\section{Legacy}

Whether IKEA is planning on replicating the URWH technologies used at its Lichtenberg branch elsewhere is not known. Nor is it clear whether it has had an impact on subsequent developers of the Berlin Eastside development, despite encouragement by borough officials to follow the IKEA example (comment at stakeholder workshop, April 2017). IKEA's presence appears to have increased the commercial attraction of the area (Sozioökonomische Beratung und Planung 2011), but it is not clear how far its environmental image in general, and its URWH technologies in particular, have contributed to this.

\section{Interpreting diversity: a cross-case comparison}

Having described the three cases separately, we now compare and interpret them in terms of the three analytical lenses developed in section 2. The lens sociotechnical imaginaries explores the visions underpinning the three URWH projects, the lens urban infrastructural context targets the interface between the site-specific projects and the city's infrastructure, whilst the third lens, institutional settings, unpacks the context within which URWH in Berlin has taken place. 


\subsection{Sociotechnical imaginaries of rainwater harvesting}

Each of the projects discussed in this paper embodies a particular vision of URWH, in terms of what it is meant to achieve, how it should be designed, whom it is supposed to benefit and what role it can play in broader issues of urban development. As the literature on sociotechnical imaginaries postulates, temporal and spatial dimensions, as well as relations between the collective and the individual, are highly formative in developing and sustaining such visions (Jasanoff, 2015).

The vision underpinning the Berliner Strasse project reflects powerfully the dominant paradigm of the time (mid-1980s) in West Berlin, in which the state was a provider and protector of social goods. It was the local state - in the form of the Senate and public housing associations - that devised this model project as a means of demonstrating that ecological urban development was compatible with social housing. At that time, public money was readily available to support this type of intervention, as was a large plot of suitable land in public hands. The sociotechnical imaginary driving those planning Berliner Strasse revolved around inserting innovative technologies of rainwater management into a new housing development and expecting them to have a beneficial effect on both on-site water flows and social relations amongst the residents. What the case study revealed is that this imaginary failed to consider the need to cultivate these sociotechnical relations in everyday practice. More generally, the case highlights how imaginaries may be powerful in designing the original sociotechnical configuration, but are liable to overlook the difficulties involved in sustaining it in practice over the longer term.

By contrast, the Sonnig Wonnig project is very much borne by its residents and initiators and the collective mode of living they have cultivated over the past 15 years. Here, an old house in need of refurbishing provided the ideal site for the experiment and Berlin's reputation for alternative and communal housing a favourable socio-cultural context. A good working relationship between the individual (the planner and the architect) and the collective (the residents, organised as an association) proved fundamental to the success of this project. The 
technical artefacts installed to retain and reuse rainwater are not seen by the initiators and residents as mere tools to help save on water consumption and running costs, but as expressions of a particular way of living representing both the environment and the people using them. This is a fitting illustration of a collective sociotechnical imaginary (Jasanoff, 2015). We can speak, here, of a tightly-knit and, therefore, powerful sociotechnical imaginary that does not conceive of the social without the technical, and vice versa. The socially cooperative and spatially bounded nature of the sociotechnical imaginary has served the project well, but arguably at the expense of its broader dissemination. The fact that the project has not been copied elsewhere suggests that imaginaries of this kind can be very place-specific, needing better institutional support in order to travel.

The very different sociotechnical imaginary underpinning the IKEA Lichtenberg project is also a product of a particular time, place and social organization. The introduction of rainwater technologies in the new store was designed not to encourage a new relationship between technology and user, but to demonstrate corporate social and environmental responsibility. The corporation as a collective, rather than any individual, is the defining instance of this sociotechnical imaginary. The technologies selected for inclusion at the store are ones that demonstrate both the breadth of IKEA's environmental responsibility - covering energy, water and wastewater - and its commercial motive to save on costs for infrastructure services. Setting the store up as the "most environmental IKEA building in Europe" (Peters, 2010) is revealing about the aspiration of corporate leadership underpinning the imaginary. It also appears to have been helpful in winning over political elites and side-lining criticism from local residents. As such, it points more clearly than the other two cases to power relations as key components of sociotechnical imaginaries and demonstrates the embroilment of sociotechnical transitions in broader processes of urban and political change (Hodson and Marvin 2010). 


\subsection{Urban and infrastructural contexts of rainwater harvesting}

What is clear from these diverse sociotechnical imaginaries is that they are each powerfully framed by urban contexts and dynamics (Coenen et al. 2012). The physical structures of the place where a project is sited, the urban policies devised to encourage rainwater retention, the economic prospects of an urban development zone, the symbolism of an alternative urban lifestyle: these and multiple other urban factors have had a significant bearing on the design and development of the three projects under study (cf. Jensen et al. 2016).

The plethora of URWH projects in Berlin is a testament to both the diversity and the dynamics of socio-spatial relations and politics in the city (cf. Bulkeley et al. 2011; Coenen et al. 2012). Thus, Berlin's reputation for being open to diverse ways of living was a key factor for the initiators of Sonnig Wonnig to decide to test their communal eco-project idea there. The Berliner Strasse project was deliberately designed to substantiate the city's budding image as an environmental innovator in the late 1980s. In terms of incentives, the three projects reflect significant shifts in policy priorities in Berlin over a 30-year period. The multiple measures to retain and reuse rainwater on the Berliner Strasse estate were the product of an interventionist local state at a time when significant public funds were available and city agencies felt responsible for resolving a housing crisis. By the time the grassroots project in Lichtenberg was planned, in the early 2000s, public support for URWH involved far less funding and more indirect support, in the form of assistance in gaining permits for rainwater technologies and incentives for users to retain rainwater on site (XXX, 2018). This is evident, too, in the IKEA Lichtenberg project, where two local policies - the split tariff for rainwater and an urban development priority for commercial zones - were important drivers for the location and environmental features of the store.

Although the physical structures of each location certainly influenced the design of the projects, it is intriguing to observe two physical dimensions where there was surprisingly little interconnectivity. Firstly, none of the three projects was created to resolve a localised problem 
of rainwater management. Site selection was determined largely by land availability. The motives for retaining and reusing rainwater were general, speaking - if at all - to a city-wide agenda, rather than a site-specific challenge. Secondly, the interfaces between the on-site infrastructure for rainwater and the surrounding urban infrastructure were often limited and not a core feature of the design. The Sonnig Wonnig project, indeed, was created explicitly to minimise use of the existing sewer and water supply systems. It needed to be connected to the public network by law, but barely interacts with it. Relieving the surrounding sewers during stormwater events does not appear to have been significant for either the public or commercial case studies. Together, what these findings reveal is that the urban and infrastructural contexts favouring URWH projects may well not be those one might expect. The fact that neither localised rainwater problems nor existing rainwater infrastructures were key drivers in any of the cases studied highlights the need to consider broader phenomena of urban context when analysing and promoting URWH schemes. We see here that change is indeed messy and contested (Jensen et al. 2016) and is powerfully shaped by broader processes of urban change (Hodson and Marvin 2010; Bulkeley et al. 2011)

\subsection{Institutional settings for urban rainwater harvesting}

The institutional context (i.e. types of institutional arrangements) predominant at the time of planning proved to be highly significant for the three URWH projects, thus reasserting a point made in the relevant literature (Tenekes et al. 2014; Rohracher 2007). Over the last 30 years policy instruments promoting URWH in Berlin have changed substantially, reflecting shifting contexts and policy priorities of Berlin's city-state government. As demonstrated in an earlier publication of ours, policies supporting URWH during this period were initially interventionist and regulatory, then complementary and collaborative and subsequently informative and facultative (XXX 2018; cf. Nickel et al 2014).

This is mirrored in the three types of projects described here, each initiated under different periods of Berlin's rainwater management policy. In the case of the Berliner Strasse settlement 
the city-state of Berlin, echoing the interventionist economic and political paradigm of the time, acted as the agenda-setter and initiator. One the one hand it required housing projects to meet ecological standards as a precondition for public funding. On the other hand it was itself active - via its own local authorities and housing associations - in planning and building this vision of an environmentally friendly social housing project.

By the mid-1990s, when Berlin faced a severe budget crisis and lacked public funds, environmental policy became less interventionist and more flexible in its approach to URWH. Private, rather than public, initiatives were now entrusted with spearheading the implementation of URWH in the city. The close relationship between the Lichtenberg borough administration and the initiators of Sonnig Wonnig, creating regulatory space for technological experimentation, is indicative of this new mode of urban water governance. Here, the city acted as an incubator for change.

This role shifted to that of an enabler of change in the course of the 2000s. The thrust of policy instruments now became primarily informative (XXX, 2018). Within this institutional framework the city provides information on various options for URWH, leaving it largely up to the private stakeholders (individuals or enterprises) to take action. This is reflected in the IKEA Lichtenberg case, in which a major global corporation was solely responsible for the site and interaction with the city and borough authorities was limited to the granting of legally required permits. Overall, our institutional lens on the three cases has revealed the crucial importance of time-sensitivity when it comes to assessing how institutional contexts frame action. The ability of the local state to promote URWH in Berlin changed significantly during just 30 years, requiring a shift in the kinds of instruments applied that - consequently influenced the kinds of URWH projects developed.

Table 2 summarises the three cases as seen through the analytical lenses of sociotechnical imaginaries, urban and infrastructural contexts and institutional settings of urban rainwater harvesting in relation to URWH. 


\section{[Table 2 here]}

\section{Conclusions}

This paper has explored the diversity of rainwater harvesting projects in a single city: Berlin. Using a comparative case-study approach, we selected three URWH projects implemented during the past 30 years that are representative of three project types: public, grassroots and commercial. The three projects we first analysed in terms of their key characteristics, relating to their context, objectives, design, actors, implementation and legacy. We then compared them, using for our interpretation three analytical lenses drawn from recent literatures on sociotechnical imaginaries (Jasanoff 2015), urban infrastructural context (Bulkeley et al. 2011) and institutional settings (Geels and Schot 2007).

The first overarching conclusion of this study is that URWH projects can, indeed, take very different forms even within one city. This observation may seem obvious, given the huge number of such projects in Berlin, but it is by no means trivial in view of the focus of previous research on single-case studies in any one city. The differences revealed related not merely to technical design but also, significantly, to the aspirations underpinning them, the actor constellations driving them and the instruments promoting them. Understanding such differences and appreciating how they can support or hinder the dissemination of particular types of URWH projects in a city is, we argue, of paramount importance for future research on urban water governance and policy. More generally, our empirical findings also provide pointers for research on sociotechnical imaginaries, highlighting the significance of temporal dynamics, bounded places and the corporation as a collective actor.

The second conclusion to make is that this diversity is co-constituted by urban contexts and dynamics. In other words, the diversity of URWH projects we observed was not just 'in' a city, but 'of' a city. The three projects we studied all reflected multiple dimensions of the 'urban', 
reflecting factors very particular to Berlin. These could be urban policies to promote URWH as a component of green housing, urban development priorities for a commercial zone, the urban symbolism of communal living or an urban budget crisis reordering state interventions. What is more, these contextual factors observed were not stable over the 30-year period of study, but shifted, sometimes quite dramatically, as in the case of public funding. This calls, in future research in human geography and STS studies, for greater attention to be paid to how URWH projects and urban factors interact at particular times in particular ways in the co-production of diversity.

Finally, having highlighted diversity 'in' and 'of' a city, we conclude by outlining how one might use this knowledge on diversity 'for' a city. What, in other words, does the diversity revealed in this paper mean for effective governance of URWH? The principal policy implication of our findings is to embrace this diversity and explore multiple pathways to mainstreaming URWH. This means that instruments that suit one particular project type may well be unsuitable or inadequate for another. Consequently, rather than attempting to roll out a one-size-fits-all strategy covering all URWH projects, it would make much more sense to devise packages of incentives and supportive structures tailored to the specific needs of particular project types. This would require a regulatory framework that endorses and rewards innovation. Particularly helpful would be a coherent, city-wide plan that identifies where URWH projects are most needed, what kinds of projects suit that locality and how these can best be promoted.

Being attentive to the importance of local context is crucial to understanding the opportunities, but also challenges, of mainstreaming URWH. In Berlin today, with its new city government dedicated to prioritising rainwater in the city, the early signs are that this message has been understood. Equipped with a new rainwater agency, created in May 2018, the city is better positioned than ever before to take a more systematic approach towards URWH. This would entail not only continuing to encourage commercial enterprises to embrace rainwater 
harvesting, but also re-engaging with alternative modes of ecological living and re-introducing URWH standards in new public buildings required to house Berlin's growing population.

\section{References:}

Bezirkamt Lichtenberg von Berlin. (2012). Lichtenberger Wirtschaft wird nachhaltig gefördert, Press Release 25.04.02. Available online at https://www.berlin.de/balichtenberg/aktuelles/pressemitteilungen/2012/pressemitteilung.305444.php (accessed 14.06.2017)

Bos, J.J., \& Brown, R.R. (2012). Governance experimentation and factors of success in sociotechnical transitions in the urban water sector. Technological Forecasting \& Social Change 79, 1340-1353.

Brown, R.R., \& Farrelly, M.A. (2009). Delivering sustainable urban water management: a review of the hurdles we face. Water Science \& Technology 59 (5), 839-846.

Brown, R.R., \& Farrelly, M.A., Loorbach, D.A. (2013). Actors working the institutions in sustainability transitions: The case of Melbourne's stormwater management. Global Environmental Change 23, 701-718.

Bulkeley, H., Broto, V.C., Hodson, M., \& Marvin, S. (2011). Introduction. In: Bulkeley, H., Broto, V.C., Hodson, M., Marvin, S. (Eds.), Cities and Low Carbon Transitions. Routledge, Abingdon, pp. 1-10.

Cettner, A., Ashley, R., Hedström, A., \& Viklander, M. (2014). Assessing receptivity for change in urban stormwater management and contexts for action. Journal of Environmental Management 146, 29-41.

Coenen, L., Benneworth, P., \& Truffer, B. (2012). Toward a spatial perspective on sustainability transitions. Research Policy 41, 968-979.

Coutard, O., Hanley, R.E., \& Zimmermann, R. (Eds). (2005). Sustaining Urban Networks. The Social Diffusion of Large Technical Systems. Routledge, Abingdon. 
De Haan, F.J., Rogers, B.C., Frantzeskaki, N., \& Brown, R.R. (2015). Editorial. Transitions through a lens of urban water. Environmental Innovation and Societal Transitions 15, $1-10$.

Fuenfschilling, L. \& Truffer, B. (2014). The structuration of socio-technical regimes Conceptual foundations from institutional theory. Research Policy 43, 772-791.

Geels, F.W. \& Schot, J. (2007). Typology of sociotechnical transition pathways. Research Policy 36, 399-417.

GSW. (1999). Dokumentation Ökologische Bauprojekte. Berliner Strasse 88, 14163 BerlinZehlendorf. Available online at: http://www.berlinklimaschutz.de/sites/default/files/ uploads/pdf/oekoprojekt berlinerstr.pdf (accessed 04.12.2015).

Hodson, M., \& Marvin, S. (2010). Can cities shape socio-technical transitions and how would we know if they were? Research Policy 39, 477-485.

IKEA (2014).IKEA Deutschland: Nachaltigkeit, Geschäftsjahr 13. IKEA Deutschland GmbH \& Co. KG.

IKEA (2010). Presseinformation: das umweltfreundlichste IKEA Haus steht bald in BerlinLichtenberg. Energiesparhaus 1.270 Tonnen weniger CO2 im Jahr.

Jasanoff, S. (2015). Future Imperfect: Science, Technology, and the Imaginations of Modernity. In: Jasanoff, S., Kim, S.-H. (Eds.), Dreamscapes of Modernity: Sociotechnical Imaginaries and the Fabrication of Power. Chicago University Press, Chicago, pp.133.

Jasanoff, S., \& Kim, S.H. (2009). Containing the Atom: Sociotechnical Imaginaries and Nuclear Power in the United States and South Korea. Minerva 47, 119-146.

Jensen, J.S., Fratini, C.F., \& Cashmore, M.A. (2016). Socio-technical systems as place-specific matters of concern: The role of urban governance in the transition of the wastewater system in Denmark, Journal of Environmental Policy \& Planning, 18(2), 234-252. 
Klimaschutzpartner. (n.d.). KlimaSchutzProjekte in Berlin. Neubau eines Einrichtungshauses in Lichtenberg. Available at: https:/www.klimaschutzpartnerberlin.de/klimaschutzprojekte. html?tx kspprojects_pi1[show] $=7$ (accessed 25-02-2016).

Madsen, H.M., Brown, R., Elle, M. \& Mikkelsen, P.S. (2017). Social construction of stormwater control measures in Melbourne and Copenhagen: A discourse analysis of technological change, embedded meanings and potential mainstreaming. Technological Forecasting \& Social Change 115, 198-209.

Mayntz, R., \& Schneider, V. (1995). Die Entwicklung technischer Infrastruktursysteme zwischen Steuerung und Selbstorganisation. In: Mayntz, R., Scharpf, F.W. (Eds), Gesellschaftliche Selbstregelung und politische Steuerung. Campus, Frankfurt am Main/New York, pp. 73-100.

Meinlschmidt, G. (2013). Handlungsorientierter Sozialstrukturatlas Berlin 2013: Ein Instrument der quantitativen, interregionalen und intertemporalen Sozialraumanalyse und -planung. Senatsverwaltung für Gesundheit und Soziales, Berlin.

Nickel, D., Schoenefelder, W., Medearis, D., Dolowitz, D.P., Keeley, M., \& Shuster, W. (2014). German experience in managing stormwater with green infrastructure. Journal of Environmental Planning \& Policy 57(3), 403-423.

Peters, O. (2010). Hej Ikeaner! Gemeinsam zum Erfolg Marzahn-Hellersdorfer Wirtschaftskreis e.V. MHW. Retrieved from: http://www.mhwk.de/hej-ikeaner/ (accessed 25-02-2016).

Rohracher, H. (2007). Die Wechselwirkung technischen und institutionellen Wandels in der Transformation von Energiesystemen. In: Dolata, U., Werle, R. (Eds), Gesellschaft und die Macht der Technik. Sozioökonomischer und institutioneller Wandel durch Technisierung. Campus, Frankfurt/New York, pp. 133-151. 
Schütze, T. (2013). Rainwater harvesting and management - policy and regulations in Germany. Water Sci. Technol.: Water Supply 13 (2), 376-385.

Senatsverwaltung für Stadtentwicklung. (2011a). Stadtentwicklungsplan Klima. Urbane Lebensqualität im Klimawandel sichern. Berlin: Medialis. (Available online at: http://www.stadtentwicklung.berlin.de/planen/stadtentwicklungsplanung/download/kli ma/step klima broschuere.pdf. (accessed 15-02-2016).

Senatsverwaltung für Stadtentwicklung. (2011b). Stadtentwicklungsplan. Zentren 3. Kulturbuch-Verlag GmbH, Berlin.

Sozioökonomische Beratung und Planung. (2011). Aktualisierung des Zentren- und Einzelhandelskonzepts für den Bezirk Lichtenberg von Berlin. Spb, Berlin/Essen.

Tagesspiegel. (2010). Zweitgrößte Ikea-Filiale der Welt eröffnet am Montag. Available at: http://www.tagesspiegel.de/berlin/lichtenberg-zweitgroesste-ikea-filiale-der-welteroeffnet-am-montag/3596550.html. (accessed 18.02.2017).

Tennekes, J., Driessen, P. P.J, van Rijswick H. \& van Bree, L. (2014). Out of the Comfort Zone: Institutional Context and the Scope for Legitimate Climate Adaptation Policy, Journal of Environmental Policy \& Planning,16:2, 241-259

Ward, S., Barr, S., Butler, D., \&Memon, F.A. (2012). Rainwater harvesting in the UK: Sociotechnical theory and practice. Technological Forecasting \& Social Change 79, 13541361.

Wolfram, M., \& Frantzeskaki, N. (2016). Cities and Systemic Change for Sustainability: Prevailing Epistomologies and an Emerging Research Agenda. Sustainability 8 (online) XXX. (2018). Rain and the city: Pathways to mainstreaming rainwater harvesting in Berlin.

\section{List of cited interviewees:}

[1] Berliner Strasse 88: Resident, 29.02.2016. 
[2] Berliner Strasse 88: Resident, 23.02.2016.

[3] Lichtenberg Borough Administration: Officer of Environmental and Nature Protection

Unit, 14.10.2016

[4] Sonnig Wonnig: Project initiators (planner and architect), 09.02.2016.

[5] Lichtenberg Borough Administration: Officer of City Planning Unit, 09.01.2017.

[6] Lichtenberg Borough Administration: Officer of City Planning Unit, 15.01.2016.

[7] Berlin Senate Department for Urban Development and the Environment: Officer of Integrative Environmental Protection Unit, 05.01.2017.

[8] Berliner Strasse 88: Engineer and construction manager, 02.03.2016

[9] Berliner Strasse 88: Resident, 11.04.2016

[10] Berliner Strasse 88: Resident, 23.02.2016

\section{$\underline{\text { Tables }}$}

Table 1: Overview of the case-study projects and their key characteristics

\begin{tabular}{|l|l|l|l|}
\hline \multicolumn{1}{|c|}{ Project } & \multicolumn{1}{|c|}{ Berliner Str. 88 } & Sonnig Wonnig & IKEA Lichtenberg \\
\hline Type & Public & Grassroots & Commercial \\
\hline Funding & $\begin{array}{l}\text { Federal and city } \\
\text { funding }\end{array}$ & $\begin{array}{l}\text { Mainly self- } \\
\text { financed }\end{array}$ & $\begin{array}{l}\text { Mainly self- } \\
\text { financed }\end{array}$ \\
\hline Year started & 1992 & 2002 & 2010 \\
\hline Technology & $\begin{array}{l}\text { Water from roofs } \\
\text { used for watering } \\
\text { green areas and } \\
\text { supplying stream }\end{array}$ & $\begin{array}{l}\text { Reuse of rain and } \\
\text { greywater for } \\
\text { domestic and } \\
\text { outdoor purposes }\end{array}$ & $\begin{array}{l}\text { Water from roofs } \\
\text { for flushing toilets } \\
\text { and watering store } \\
\text { greenhouse }\end{array}$ \\
\hline Actors & $\begin{array}{l}\text { City and borough } \\
\text { authorities, public } \\
\text { housing } \\
\text { associations, } \\
\text { engineering } \\
\text { consultants, } \\
\text { residents }\end{array}$ & $\begin{array}{l}\text { Two initiators, } \\
\text { residents, also } \\
\text { engineering } \\
\text { company, borough } \\
\text { administration }\end{array}$ & $\begin{array}{l}\text { IKEA Sweden \& } \\
\text { subsidiaries, } \\
\text { borough } \\
\text { administration, also } \\
\text { Berlin Water } \\
\text { Company }\end{array}$ \\
\hline
\end{tabular}

Source: own compilation 
Table 2: The three cases seen through the analytical lenses

\begin{tabular}{|l|l|l|l|}
\hline \multicolumn{1}{|c|}{ Project } & \multicolumn{1}{|c|}{ Berliner Strasse } & \multicolumn{1}{c|}{ Sonnig Wonnig } & \multicolumn{1}{c|}{ IKEA Lichtenberg } \\
\hline $\begin{array}{l}\text { Sociotechnical } \\
\text { imaginaries }\end{array}$ & $\begin{array}{l}\text { Pioneering } \\
\text { compatibility } \\
\text { between social } \\
\text { housing and } \\
\text { ecological } \\
\text { innovations }\end{array}$ & $\begin{array}{l}\text { Creating affordable } \\
\text { and attractive urban } \\
\text { ecological housing } \\
\text { with alternative } \\
\text { technologies }\end{array}$ & $\begin{array}{l}\text { Promoting corporate } \\
\text { environmental } \\
\text { responsibility with } \\
\text { innovative } \\
\text { technologies }\end{array}$ \\
\hline $\begin{array}{l}\text { Urban- } \\
\text { infrastructural } \\
\text { contexts }\end{array}$ & $\begin{array}{l}\text { Moderate relevance } \\
\text { for local water } \\
\text { resources }\end{array}$ & $\begin{array}{l}\text { Minimal connection to } \\
\text { urban infrastructure }\end{array}$ & $\begin{array}{l}\text { Low relevance of } \\
\text { local rainwater } \\
\text { infrastructure }\end{array}$ \\
\hline $\begin{array}{l}\text { Institutional } \\
\text { settings }\end{array}$ & $\begin{array}{l}\text { City as initiator and } \\
\text { provider of socially- } \\
\text { oriented URWH }\end{array}$ & $\begin{array}{l}\text { City as incubator for } \\
\text { alternative eco- } \\
\text { lifestyles }\end{array}$ & $\begin{array}{l}\text { City as enabler of } \\
\text { commercial } \\
\text { environmental } \\
\text { innovation }\end{array}$ \\
\hline
\end{tabular}

Source: own compilation 